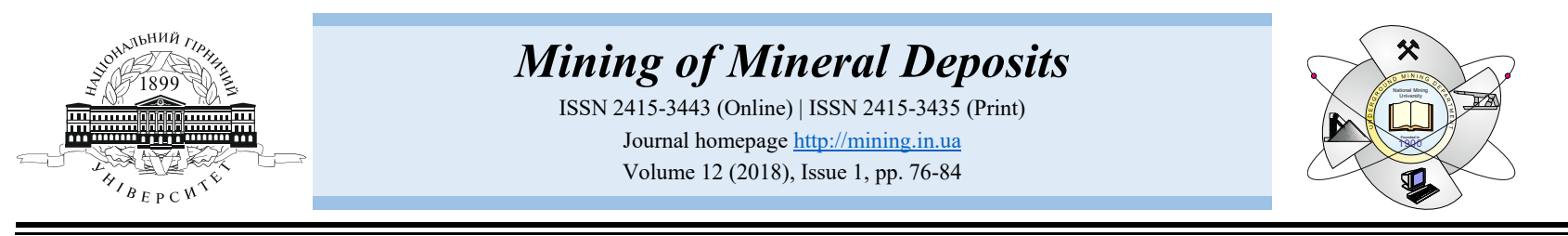

\title{
DEVELOPMENT OF A RESEARCH METHODOLOGY AND ANALYSIS OF THE STRESS STATE OF A PARTING UNDER THE JOINT AND DOWNWARD MINING OF COAL SEAMS
}

\author{
I. Kovalevska ${ }^{1 *}$, M. Barabash ${ }^{2}$, V. Snihur ${ }^{3}$ \\ ${ }^{I}$ National Mining University, Dnipro, Ukraine \\ ${ }^{2}$ LLC "DTEK Energy", Kyiv, Ukraine \\ ${ }^{3}$ MM "Ternivske", PJSC "DTEK Pavlohradvuhillia", Pavlohrad, Ukraine \\ *Corresponding author: e-mail kovalevska_i@yahoo.com, tel. +380567560047,fax: +380563742184
}

\begin{abstract}
Purpose. The investigation of the stress-strain state (SSS) of a parting under the joint and downward mining of coal seams.

Methods. The studies have been carried out on the basis of a computational experiment by means of the finite elements method, mining observations of rock pressure manifestations and their comparative analysis.

Findings. A research methodology has been developed of the parting rocks state under the joint and downward mining of coal seams.

Originality. The patterns of the stress-strain state change of the parting rocks have been determined in the process of joint mining of two coal seams by the descending order.

Practical implications. The conducted researches will make possible to improve stability of mine workings and their repeated use.
\end{abstract}

Keywords: coal seams, joint mining, parting, computational experiment, stability

\section{INTRODUCTION}

At the present stage of coal mining in Ukraine and, especially, in Western Donbas, one of the trends for mining works intensification is the joint mining of two or more coal seams by the descending order. This increases the concentration of works and facilitates ultimately the lowering of coal production costs. However, for the specific conditions of Western Donbas, there were not investigated the questions of parting rocks stability, the thickness of which in the main range of $20-50 \mathrm{~m}$ does not allow to assign the jointly mined coal seams to contiguous grade of seams. At the same time, the soft coal-bearing rocks, under the severe exposure of mining pressure manifestations, do not always keep continuity and, thus, a mining-engineering situation arises of weakening areas junction of bottom rocks of overlying and roof rocks of underlying seams, which are jointly mined. And this predetermines the risk of rocks stability loss along the whole thickness of a parting with the forthcoming accident consequences, especially in the reused extraction workings.

\section{THE MAIN PART}

\subsection{Systematization of mining and geological conditions of Western Donbas}

The analysis of the geological data of Western Donbas mines shows a high degree of instability in the partings structure caused by both as the broad range of thickness variation of rock layers (even within a single extraction area), so by the constant replacement of one lithotype by another. There are four lithotypes in the formation of a parting (coal, mudstone, siltstone and sandstone) with thickness variation from 0 to $12-14 \mathrm{~m}$. The mineable coal seams are mainly located at a distance of $20-25 \mathrm{~m}$. However, in separate areas of the mine fields, the thickness of a parting may increase to $H_{p}=40-50 \mathrm{~m}$, as the coal seams located within this thickness are not reasonable for mining due to the mining, geological and technical reasons. Thus, the main range of parting thickness variation amounts to $H_{p}=20-50 \mathrm{~m}$.

The analysis of the parting structure showed that it can be mainly assigned to both as coarse-grained, so medium-bedded categories, but in some areas a thinbedded formation appears. If to generalize the parting

(C) 2018. I. Kovalevska, M. Barabash, V. Snihur. Published by the National Mining University on behalf of Mining of Mineral Deposits.

This is an Open Access article distributed under the terms of the Creative Commons Attribution License (http://creativecommons.org/licenses/by/4.0/),

which permits unrestricted reuse, distribution, and reproduction in any medium, provided the original work is properly cited. 
group with a minimal thickness $\left(H_{p}=20-25 \mathrm{~m}\right)$, it should be noted that it is formed by (usually) from 3 to 19 rock layers and coal inter-layers, but the main range is constituted by $5-8$ units. With the excessive thickness of a parting the main range of structural units increases by $1.5-2$ times. Thus, the first sign of the parting structure systematization is the preferred thickness of the constituent layers: coarse-grained and medium-bedded thickness or medium- and thin-bedded thickness.

The second sign of the systematization is the location (height wise $H_{p}$ ) of the coal seams with non-operational thickness and inter-layers, because their very weak coherence (or total absence of it) has a significant influence on the structural transformations of rocks in the zones of the rock pressure manifestations in the period of the coalface works. For example, the location of the coal interlayer $\mathrm{C}_{9}{ }^{1}$ in approximate middle of the parting thickness $H_{p}=23-25 \mathrm{~m}$ of the seams $\mathrm{C}_{9}$ and $\mathrm{C}_{10}{ }^{h}$ causes (reasonably likely) the upper boundary of the hinged and block displacement zone when the seam $\mathrm{C}_{9}$ is extracted. In the same area of the mine field in the parting $\mathrm{C}_{8}{ }^{l}$ and $\mathrm{C}_{9}$ the coal seam $\mathrm{C}_{8}{ }^{l}$ and the nameless inter-layer are located closer to the mineable seam $\mathrm{C}_{8}{ }^{l}$ and, in the case of the main roof rocks displacement they most likely will not determine the upper boundary of the massif separation into blocks. The same is the case for the inter-layers location in the upper part of the parting: they do not affect the formation of the hinged and block displacement zone of the roof rocks in mining of the underlying coal seam; at the same time, these inter-layers can have an active influence on the sizes of an area of the bottom broken rocks of the mineable upper layer of a parting.

The third sign in the grouping of parting formation features is the availability of sandstone, its thickness and its location throughout the height of a parting:

- a heavy (3-4 $\mathrm{m}$ and more) sandstone in the lower layers of the main roof or sandstone (up to $3 \mathrm{~m}$ ) in the upper layers of the main roof facilitates a significant restriction of the hinged and block displacement zone;

- sandstone with medium thickness in the main bottom of the seam restricts dramatically its weakening depth;

- low-thickness sandstone (less than $1 \mathrm{~m}$ ) in the seam bottom sometimes facilitates the intensification of heaving processes and the extension of structural disturbances deep into massif.

The fourth identified sign is the strength characteristics and the degree of impact on them of the weakening factors of water content and fracturing. The reduced strength properties predict an increase in the extension of structural disturbances of the roof and bottom rocks of the mineable seams, and with restricted thickness of a parting this can destabilize it.

The fifth sign expresses the combination of the parting thickness and the number of the mineable seams in it. For example, even at a high value $H_{p}=45-50 \mathrm{~m}$ between the seams $\mathrm{C}_{8}^{l}$ and $\mathrm{C}_{10}{ }^{h}$ the stability of a coalbearing massif in the process of sequential mining by the descending order of a seam $\mathrm{C}_{9}$ may be disturbed.

As a result, the generalization of the parting structure features has made it possible to generate for further researches five following variants, which characterize most fully the mining and geological conditions under the downward and joint mining of coal seams in Western Donbas. In view of the studied process, all variants of the parting structure presuppose the possibility of its stability disturbance under the impact of one or several unfavorable factors, taking into account the stated signs of mining and geological conditions systematization (Fig. 1).

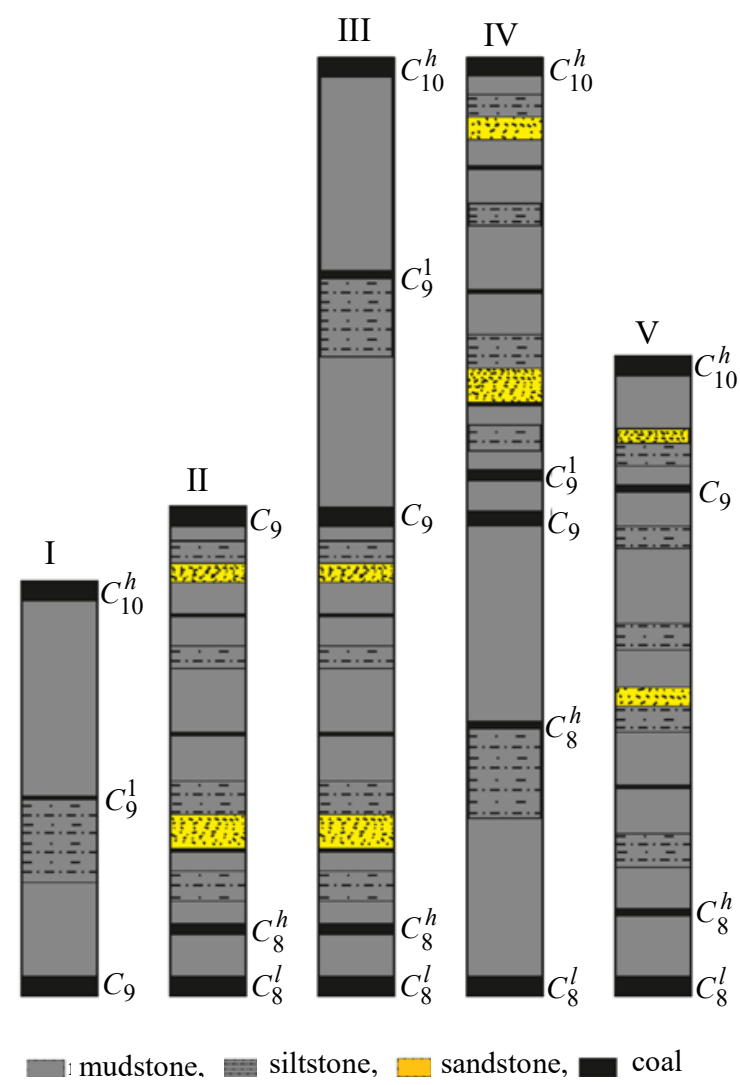

Figure 1. Variants $(I-V)$ of the parting structure, with possible loss of its stability under the downward and joint mining of two, three coal seams in Western Donbas

\subsection{The formulation of research task}

This separation is a necessity for a complex of computational experiments performing, since it is not possible to combine the wide variety of parting structures in a single geomechanical model. Thus, only by the factor of parting structure diversity, there is an obvious need for a multivariant modeling of its rocks state. Five structural variants, presented in Figure 1, can be partially reduced with the use of the results of variants I and II studies to examine variants III and IV; however, the final decision should be made only on the basis of the primary (test) calculations of all five structural variants. Within the framework of each parting structure, there is a need to observe the impact of the main geomechanical factors on its stability, and then, on the basis of identified patterns of this influence, to build a risk assessment system of mining pressures perturbations, which appear in certain areas of partings in Western Donbas in general and in similar mining and geological conditions of other coal deposits.

The accumulated experience of geomechanical processes modeling in Western Donbas conditions and extensive mine observation base (Simanovich \& Srebnyy, 1976; Usachenko, Cherednichenko, \& Golovchanskiy, 1990; Skipochka, Mukhin, \& Chervatyuk, 2002; Ko- 
valevs'ka, Vivcharenko, \& Snigur, 2013; Bondarenko et al., 2014) substantiate (at the preliminary assessment level) the need of the following parameters consideration.

Firstly, in the vast majority of modern techniques for geomechanical processes calculation the depth $H$ of mining is taken into account as a basic parameter, which defines not only the initial state of the virgin massif, but also the intensity of the rock pressure perturbation around mine workings.

Secondly, on the comparison basis of parameters of the rock pressure manifestations with the strength characteristics of located there lithotypes, the areas of parting rocks disturbances are established, which should be calculated in the first place. The generalized assessment of the strength characteristics of a parting in general is recommended to perform by the value of so-called average compressive resistance $R$, mentioned in the normative techniques (KD 12.01.01.201-98, 1998; SOU 10.1.001.85790.011, 2007). The parameter $R$ does not preclude the use of the calculated compressive resistance (determined by the action of the factors weakening the rock according to the above mentioned technique) of each of the roof rocks $R_{i}^{r}$ and the bottom rocks $R_{i}^{b}$ lithotypes of the mineable seam (index " $i$ " - is the numbering of the lithotype from the coal seam). The recent indicators are involved in the differentiated determination of the sizes of the disturbances areas in each lithotype of a parting.

Thirdly, the thickness of a parting $H_{p}$ is the variable value even within a single extraction segment, say nothing of the wing of the mine field or adjacent mine fields. Therefore, a range of changes $H_{p}$ is being investigated for each of the selected parting structures.

Fourthly, the impact of the lithotypes thickness variation (although in a limited range) on the state of a parting is analyzed. To arrange the assessment of their impact, the lithotypes thicknesses are specified as: for the coal seam $m^{c}$, for roof rocks $m_{i}^{r}$ and for bottom rocks $m_{i}^{b}$ of the mineable seam. It is obvious that in a number of subsets of partings structures, the fluctuations of $H_{p}, m_{i}^{r}$ and $m_{i}^{b}$ parameters are interrelated.

In terms of the stated positions an algorithm of multivariant calculation methodology has been developed, which consists of a series of sequential stages.

Stage 1. The source database formation. The diversification of computational experiment variants implies variety of the investigated parameters within a certain framework, specific for mining and geological conditions of the coal seams mining in Western Donbas.

The first parameter is the depth $H$ of mining adopted in the range of $H=200-600 \mathrm{~m}$, which is proved in a number of works (Kovalevska, Fomychyov, \& Vyvcharenko, 2010; Bondarenko, Kovalevs'ka, \& Fomychov, 2012; Kovalevs'ka, Vivcharenko, \& Snigur, 2013; Bondarenko et al., 2014) and is fully conformed to real depths of the current coal-face operation and in the future.

The second parameter is the strength characteristics of the lithological varieties, forming a parting; the following conventional signs have been introduced for calculation convenience and subsequent analysis: $\sigma_{c o m}^{c}-$ the ultimate compressive strength of the coal seams and the inter-layers, $\sigma_{\text {com }_{i}}^{r}$ and $\sigma_{\text {com }_{i}}^{b}$ - the ultimate compressive strength of the roof and bottom rocks of a seam, respec- tively ( $i-$ is the number of a rock layer, beginning with the mineable coal seam).

The study of the physical and mechanical properties of the coal-bearing strata of Western Donbas in works (Usachenko, 1979; Usachenko, Cherednichenko, \& Golovchanskiy, 1990), their specific systematization in works (Bondarenko, Kovalevs'ka, \& Fomychov, 2012; Bondarenko, Kovalevskaya, Simanovich, \& Snihur, 2014) and data from the geological services of mines have led to the following averaged ranges of compressive resistance (in the sample) for lithotypes: coal $-30-40 \mathrm{MPa}$; mudstone $-10-20 \mathrm{MPa}$; siltstone - $15-25 \mathrm{MPa}$; sandstone $30-60 \mathrm{MPa}$. The consideration of water saturation and fracturing factors, which weaken the rock, is carried out according to normative technique (SOU 10.1.001.85790.011, 2007). As a result, in view of problem structures (in terms of stability) of a parting (Fig. 1), three variants are distinguished for the computational values distribution of the strength characteristics of lithotypes:

- variant $\mathrm{A}$-soft watered rocks along the lower boundary of the compressive resistance: coal $R^{c}=20 \mathrm{MPa}$, mudstone $R_{i}^{r, b}=5 \mathrm{MPa}$, siltstone $R_{i}^{r, b}=10 \mathrm{MPa}$, sandstone $R_{i}^{r, b}=20 \mathrm{MPa}$;

- variant $\mathrm{B}$ - watered rocks along the upper boundary of the compressive resistance: coal $R^{c}=30 \mathrm{MPa}$, mudstone $R_{i}^{r, b}=10 \mathrm{MPa}$, siltstone $R_{i}^{r, b}=15 \mathrm{MPa}$, sandstone $R_{i}^{r, b}=45 \mathrm{MPa}$;

- variant $\mathrm{C}$ - unwatered rocks along the upper boundary of the compressive resistance: coal $R^{c}=40 \mathrm{MPa}$, mudstone $R_{i}^{r, b}=20 \mathrm{MPa}$, siltstone $R_{i}^{r, b}=25 \mathrm{MPa}$, sandstone $R_{i}^{r, b}=60 \mathrm{MPa}$.

Thus, the three variants of strength characteristic combinations of all lithotypes cover the basic range of parting properties in Western Donbas.

Parameter $R$ - the average calculated compressive resistance of the parting rocks is determined by the normative technique (SOU 10.1.001.85790.011, 2007), with account of the influence ratios against the mineable coal seam.

The third parameter is the thickness of a parting $H_{p}$; its range of variation $\left(H_{p}=20-50 \mathrm{~m}\right)$ is related to variants $(\mathrm{I}-\mathrm{V})$ of the parting structures, shown in Figure 1, as well as the thickness variation intervals of separate lithotypes in a parting. The substance of correlation is that, for example, with increase of $H_{p}$ by $3 \mathrm{~m}$ the thickness of one or more (in total) lithotypes should be increased by the same $3 \mathrm{~m}$. There two sub-variants appear: the increase (decrease) of the thickness of the weakest lithotype (mudstone) and the hardest rock, sandstone. In the first sub-variant of the parting structure a value $H_{p}$ is found out, at which its stability is achieved; in the second sub-variant, the sandstone thickness $m_{i}^{r}$, at which the parting stability is provided at the given value of $H_{p}$. Therefore, a "third parameter" refers to the parameters $H_{p}$ and $m_{i}^{r, b}$ combination and matching.

The described approach to the parting structure variation, at first glance, implies a large number of calculated variants. However, this is not the case for the following reasons:

- firstly, the main variants of the $\mathrm{I}-\mathrm{V}$ structures complement each other and if, for example, it is established that, at $H_{p}=23.5 \mathrm{~m}$ the I parting structure is stable, so the upper part of the IV variant structure will be stable (all things being equal) under certain assumptions; 
- secondly, it is sufficient (as a rule) three subvariants of calculated structures to find its stable form and then to detail the parameters of depositing in the area of already found stable structure.

Stage 2. The substantiation of geomechanical model of parting's behavior. According to the methods of geomechanical processes modeling with the use of FEM (Fadeyev, 1987), which are described in sufficient detail for the conditions of Western Donbas in works (Kovalevska, Fomychyov, \& Vyvcharenko, 2010; Bondarenko, Kovalevs'ka, \& Fomychov, 2012; Kovalevs'ka, Vivcharenko, \& Snigur, 2013; Bondarenko et al., 2014), a parting model is constructed on the basis of following main positions.

The model features a part of the coal-bearing formation, including a parting, which is sufficient to represent fully all the manifestations of the rock pressure caused by the coal-face works. For this purpose, during the initial testing of a model with deliberately oversized dimensions, the areas, where the fluctuations of the main stress components do not exceed $10 \%$ are cut off. This indicator is proved in the work (Bondarenko, Hardygora, Symanovych, Sotskov, \& Snihur, 2016) and by1.5 - 2 times lower than the error value admissible for mining calculations. This technique reduces significantly the sizes of a model, and this saves computational and temporal resources without loss of the calculation accuracy.

The dimensions of the spatial model are substantiated, given the described circumstances, as the areas of the rock pressure manifestations have a three-dimensional distribution form.

Along the strike in the process of its extraction according to the existing ideas (Chernyak, 1984; Baysarov, Il'yashov, \& Demchenko, 2005; Kovalevs'ka, Vivcharenko, \& Snigur, 2013) the unloading zone above and behind the longwall is taken into account, as well as the side bearing pressure zone in the edge area of a seam. The analysis of current modeling results (Kovalevska, Fomychyov, \& Vyvcharenko, 2010; Kovalevs'ka, Vivcharenko, \& Snigur, 2013; Bondarenko et al., 2014) indicates that the unloading zone is stabilised at a distance (coordinate $Z$ ) to $30-40 \mathrm{~m}$ from the edge of a seam (or along the length of end section of the longwall); therefore, with some reliability of the unloading zone presentation, a distance $z=50 \mathrm{~m}$ is accepted from extraction drift to the longwall side (Fig. 2). The side bearing pressure zone is generally extended to $15-25 \mathrm{~m}$ towards a virgin massif along the strike; in terms of reliability of the side bearing pressure zone representation an area is modeled with a length of $30 \mathrm{~m}$ from extraction drift towards a virgin massif.

On down-dip and up-dip of a seam, there appears a front bearing pressure zone ahead of the breakage face and the unloading zone behind it. Various researches in this area confirm that the front bearing pressure zone extends to $10-15 \mathrm{~m}$ as a result of modeling (Skipochka, Mukhin, \& Chervatyuk, 2002; Kovalevs'ka, Vivcharenko, \& Snigur, 2013; Bondarenko et al., 2014) from mine observations (Simanovich \& Srebnyy, 1976; Kovalevs'ka, Vivcharenko, \& Snigur, 2013; Bondarenko et al., 2014), the displacement intensification in the extraction drifts is observed at an average from 10 to $30 \mathrm{~m}$ before the longwall approach.

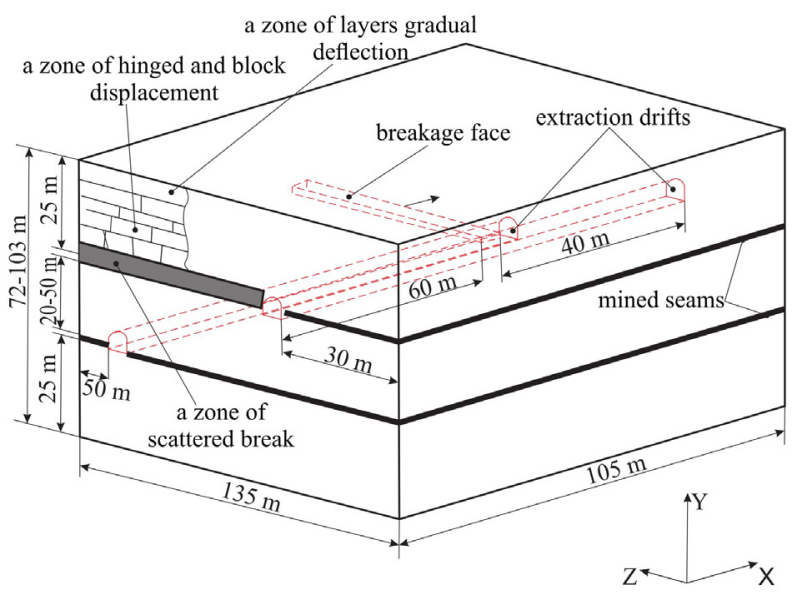

Figure 2. To substantiation of the spatial models dimensions for a parting SSS calculation

With some reliability of the front bearing pressure zone presentation, the model has a length of $40 \mathrm{~m}$ on updip of a seam. On down-dip of a seam, the unloading zone is developed with active displacements of coaloverlaying formation. On the basis of the same totality of existing studies in Western Donbas, it is known that the stabilization of the roof rocks displacements processes is observed at a distance of $30-60 \mathrm{~m}$ behind the breakage face; we take up this distance $x=60 \mathrm{~m}$ in the developed geomechanical model (Fig. 2).

Throughout the height in the roof of the mineable seam all specific zones of the coal-overlaying formation displacement should be represented in accordance with existing representations (Simanovich \& Srebnyy, 1976; Chernyak, 1984; Baysarov, Il'yashov, \& Demchenko, 2005; Kovalevs'ka, Vivcharenko, \& Snigur, 2013): the zone of scattered break, the zone of hinged and block displacement and the zone of layers gradual deflection without discontinuity. In modern FEM studies, the beginning of the last zone as a rule is accepted as the upper boundary of the model. To improve the representation reliability of two lower displacement zones, a decision has been taken to model two or three rock layers of their gradual deflection zone without discontinuity to the height of $10 \mathrm{~m}$. The underlying zone of hinged and block displacement is assessed in different works on the average up to $10-12$ extraction heights of the coal seam $m_{h}{ }^{c}$. With the most common for Western Donbas value of $m_{h}{ }^{c}=1.03-1.05 \mathrm{~m}$ the hinged and block displacement zone extends to the height of $10.3-12.6 \mathrm{~m}$. The lower scattered break zone usually amounts to $(2-3) m_{h}{ }^{c}$, and this in absolute expression is about $2-3 \mathrm{~m}$. By summing the zones specified dimensions, we deduce the height of a model to the roof of the upper layer of a parting about $20-25 \mathrm{~m}$. In this connection, it should be noted that, according to the requirements of the normative methodology (SOU 10.1.001.85790.011, 2007), in calculation of the rock pressure on mine workings support in the area of coal-face works influence the rock layers should be taken into account, which are deposited to the height of the roof not less than $20 \mathrm{~m}_{h}^{c}$. If to compare these specified values, we can make the conclusion about the validity of the accepted distance of $25 \mathrm{~m}$ to the roof of the upper layer in the developed geomechanical model. 
By the depth of the coal-bearing formation from the upper mineable seam the thickness $H_{p}$ of a parting and some distance to the bottom of the underlying mineable seam are modeled. This distance is determined mainly by the depth of the bearing pressure zone extent into the bottom. Analysis of the modeling results of the coal-face works in the conditions of Western Donbas (Kovalevska, Fomychyov, \& Vyvcharenko, 2010; Kovalevs'ka, Vivcharenko, \& Snigur, 2013; Bondarenko et al., 2014) shows the extent of stress concentrations to $15-18 \mathrm{~m}$ into the bottom of the mineable seam. With some representation reliability of the front bearing pressure zone in the bottom, the position of the lower boundary of a model is taken up at a depth of $25 \mathrm{~m}$ from the lower mineable seam.

As a result, taking into account the thickness $H_{p}$ of a parting and thickness of mineable seams, the model height will be $y=72-103 \mathrm{~m}$. All dimensions of the geomechanical models are represented in Figure 2.

Stage 3. The boundary conditions and mechanical characteristics of the models elements. The calculation of the geomechanical model SSS is performed in elasticplastic setting with an approximation to the actual diagram of lithotypes deformation by bilinear function (Sokolov, 1997; Zadavin, Gusel'nikov, V'yunikov, \& Litovchenko, 2009; Kovalevs'ka, Vivcharenko, \& Snigur, 2013; Bondarenko et al., 2014). Such a setting has two positive points. Firstly, the representation adequacy of real geomechanical processes is being improved. Secondly, the "step-by-step" SSS calculation algorithm makes it possible to vary $H$ parameters within a single computational experiment. Thereat, it is significantly reduced the number of calculated variants, required to find the regularities of the parting stable state correlation with its geomechanical parameters.

The interaction of adjacent lithological varieties is modeled by the friction condition without coherence, and this is considered the most adequate (Kovalevska, Fomychyov, \& Vyvcharenko, 2010; Kovalevs'ka, Vivcharenko, \& Snigur, 2013) in the zone of active displacements of the massif where horizontal movement of layers relatively to each other disturbs the already weak coherence (Zborshchik \& Nazimko, 1986). This boundary condition complicates the SSS calculation, but makes it possible to obtain more reliable results.

As part of the elastic-plastic calculation, the following mechanical characteristics of lithotypes are accepted: compressive strength and tensile strength, deformation modulus, and Poisson's ratio. The compressive strength is the initial parameter for determination of the calculated compressive resistance value of each lithotype according to normative technique (SOU 10.1.001.85790.011, 2007), with account of water saturation and fracturing factors impact, which weaken the rock. The tensile strength of all lithotypes of Western Donbas is quite low (about $1.2-11.9 \mathrm{MPa}$ based on geological surveys) and, with account of weakening factors, it can be taken up as equal to zero with some redundancy in assessment of the parting stability. The deformation modulus and the Poisson's ratio have been determined according to geological surveys, data of IGTM named after M.S. Poliakov of the NAS of Ukraine and test results of the mechanical properties of rocks in Western Donbas (Usachenko, 1979; Usachenko, Cherednichenko, \& Golovchanskiy, 1990).
The mounting and security system of mine workings is not modeled within the performed task because of their small impacts (Kovalevska, Fomychyov, \& Vyvcharenko, 2010; Bondarenko, Kovalevs'ka, \& Fomychov, 2012; Kovalevs'ka, Vivcharenko, \& Snigur, 2013; Bondarenko et al., 2014) on SSS of the parting areas removed from mine workings, where the question of stability degree is being solved. This technique, without compromising the calculation accuracy, makes it possible to reduce significantly the time and computational resources in performing a series of computational experiments.

Stage 4. Identification criteria and representation technique of the parting structural transformations. By the completely formed geomechanical model the calculation is performed of its SSS at the maximal development depth $H=600 \mathrm{~m}$; the remaining set of values $H$ (in the range of $200-600 \mathrm{~m}$ ) will be determined automatically when the calculation is stopped intermediately at any specific time.

In the course of calculation the distribution of all stress components is analyzed, but most of the focus is on horizontal $\sigma_{x}, \sigma_{z}$ and stress intensity $\sigma$ in terms of a task for identifying the parting rocks structural transformations, of roof of the upper and bottom of the lower seams. Within the framework of the fourth stage, the task of identifying the structural transformations of the coalbearing massif is divided into four sub-stages.

At the first sub-stage, the SSS calculation is performed of a model with the cohesive rock layers and coal seams (inter-layers), except for the rocks of a scattered break zone. The curves of the components $\sigma$ distribution are analyzed at the time of the upper seam mining and the cross-sections coordinates are set in each lithotype, where it is possible to divide the lithotype into blocks. The criterion for bringing about of vertical rupture cracks in the bending of rock layers and coal seams consists in the action (in this cross-section) of tensile stresses $\sigma_{x}$ or $\sigma_{z}$, but the boundary condition are the equations:

$\sigma_{x}=0 ; \sigma_{z}=0$.

When performing the criteria (1) in any lithotype, it can no longer be modeled in a cohesive manner, and its state representation adequacy is provided by a vertical fracture creation to the depth (according to the lithotype thickness) of criteria execution.

As it is known, at bending of rock layers and coal seams together with the tensile $\sigma_{x}$ or $\sigma_{z}$ area formation there is a compressive area in the same section of lithotype; if the intensity level of stresses $\sigma$ exceeds the calculated compressive strength value here, then the destruction of the given area happens and the criterion consists in a condition:

$\sigma \geq R_{i}^{r, b, c}$.

When two criteria (1) and (2) are performed simultaneously in the analyzed section, the lithotype loses continuity along the whole its thickness and is divided into two parts that can interact with each other only by means of thrust forces (compressive $\sigma_{x}$ or $\sigma_{z}$ ).

According to the described technique the changes are made in the structure of all lithotypes where criteria (1) 
and (2) are performed, and this is expressed by the term "structural transformations".

At the second sub-stage of the SSS calculation, all the lithotypes discontinuities determined at the first substage should be introduced into a geomechanical model. The components $\sigma_{x}, \sigma_{z}, \sigma$ distribution field is studied, and if the criteria (1) and (2) are performed, the new cross sections of the lithotypes structure are amended accordingly. Here, the special attention is paid to the lithotypes of the roof and bottom of the upper seam, immediately adjacent to the structural changes, which were identified at the first sub-stage. This is due to the fact that lithotypes with discontinuities undergo a higher deformation under the influence of rock pressure, with the greatest impact on neighbouring layers and coal seams (inter-layers).

At the third stage of the SSS calculation of coalbearing massif the mining of lower seam of a parting with representation of all structural transformations of the roof and bottom rocks of the upper seam is modeled. The lithotypes of the roof and the bottom of the lower seam still remain cohesive. The analysis of the curves $\sigma_{x}$, $\sigma_{z}$, and $\sigma$ is performed in the same way for the purpose of identification of disturbances in the lithotypes of the roof and bottom of the lower seam, as well as the occurrences of new disturbances in the lithotypes of the roof and bottom of the upper seam.

The fourth stage consists in the geomechanical model SSS calculation of the stage 3 , but with all structural transformations of the coal-bearing formation, which were identified before. The latest SSS calculation is the final for assessment of the parting stability.

Thus, the four-staged technology for identification and recording of the structural transformations of parting rocks is proved, which makes it possible to improve the adequacy and reliability of the computational experiments results in assessment of the coal-bearing massif stability under the joint and downward mining conditions of coal seams in Western Donbas.

\section{ANALYSIS OF THE COMPUTATIONAL EXPERIMENT RESULTS}

\subsection{Specifics of the horizontal stresses field distribution along the extraction panel}

Horizontal stresses $\sigma_{x}$ make the most informative recording of the degree and direction of the rock layers bending in a parting and are used in two functions: tensile $\sigma_{x}$ determine the discontinuity areas caused by vertical rupture cracks; the concentrations of compressive $\sigma_{x}$ are significant in determining the areas of rock layers weakening caused by compression. These factors define reasonability of the specifics consideration of horizontal stresses fields' distribution in longitudinal section $Y X$ of the extraction panel.

In longitudinal section $Y X$ of the extraction panel, the following trends in a parting structure influence are distinguished (Fig. 3):

- in the predominantly thin- and medium-bedded structure, there is an active bending of most of the rock layers, except for a few adjacent to the unloading zone of already worked out extraction panel of the seam $\mathrm{C}_{10} h$;

- in the predominantly medium- and coarse-bedded structure, the area of moderate layers deflection extends approximately to the medial thickness of a parting, but also below it in heavy lithotypes there are areas of low impact of bending stresses $\sigma_{x}$;

- only in the immediate and lower layer of the main roof of the seam $\mathrm{C}_{8}{ }^{l}$ the field $\sigma_{x}$ manifestations are active, and it makes possible to predict the weakening of the given massif areas.

Thus, an analysis of the horizontal stresses $\sigma_{x}$ distribution confirmed the significant influence of the parting rocks structure on the parameters of rock pressure manifestations.

\subsection{The research results and stresses intensity analysis}

There were considered several fragments of the integral parameter distribution - stresses intensity $\sigma$ - the value of which predetermines the occurance of prelimiting and superlimiting states of the rock.

In longitudinal section $Y X$ of the extraction panel (Fig. 4) the field $\sigma$ parameters make it possible to predict the unstable state of the parting rocks both as in the front bearing pressure zone, so in the unloading zone behind the breakage face along the seam $\mathrm{C}_{9}$ :

- bottom rocks of the seam $\mathrm{C}_{10}{ }^{h}$ are definitely destroyed to a depth of $5.3 \mathrm{~m}$ along the whole length $x$ of the extraction panel;

- in the unloading zone, the fracture nuclei of bottom rocks of the seam $\mathrm{C}_{10}{ }^{h}$, although they have a restricted distribution throughout the height of each lithotype (in the range of $0.5-1.3 \mathrm{~m}$ ), but their development on down-dip and up-dip of a seam reaches 5-12 m; these nuclei of weakening appear up to the seam $\mathrm{C}_{9}^{\prime}$ in the middle part of a parting;

- with the above-mentioned nuclei of weakening, the local discontinuity areas in the roof of the seam $\mathrm{C}_{9}$ close, and this determines the probability of the unstable state of a parting as a whole;

- a similar geomechanical situation occurs in the front bearing pressure zone, which is worsened by the extending of a vast area of continuous weakening of the roof rocks of the seam $\mathrm{C}_{9}$ to the height up to $10.7 \mathrm{~m}$ and width to $11-12 \mathrm{~m}$.

Thus, at a reduced thickness of a parting (about $23-28 \mathrm{~m}$ ), there is a possibility of its unstable state, especially in the front and side bearing pressure zones during the underlying seam mining.

The increase in thickness of a parting to $45-50 \mathrm{~m}$ under the joint mining of seams $\mathrm{C}_{10}{ }^{h}$ and $\mathrm{C}_{8}{ }^{l}$ changes significantly the stresses $\sigma$ intensity field distribution and the results of its stability assessment.

In the predominantly thin- and medium-bedded structure of a parting in longitudinal section $Y X$ the pattern of stresses $\sigma$ intensity distribution is as follows (Fig. 5):

- extraction panel along the seam $\mathrm{C}_{10}{ }^{h}$ which has already been worked out, creates a bottom unloading area extending to $23-31 \mathrm{~m}$;

- in the roof of a seam $\mathrm{C}_{8}{ }^{l}$ both as in the front bearing pressure zone, so in the unloading zone (in the case of coalface works), the weakening areas extend to $25-26 \mathrm{~m}$, but they are local in nature, and occupy only part of each lithotype thickness; besides, in the middle of these areas the lithotypes are located in a cohesive state along the whole their thickness;

- continuous weakening area extends to the front bearing pressure zone only to the height of $5.2-5.9 \mathrm{~m}$. 
(a)

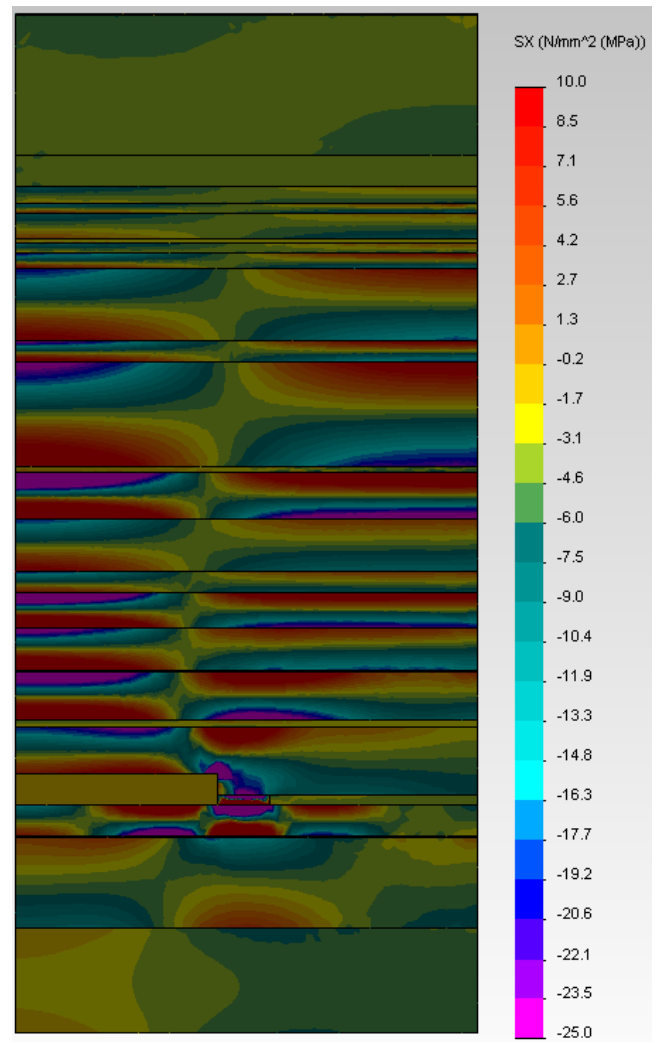

(b)

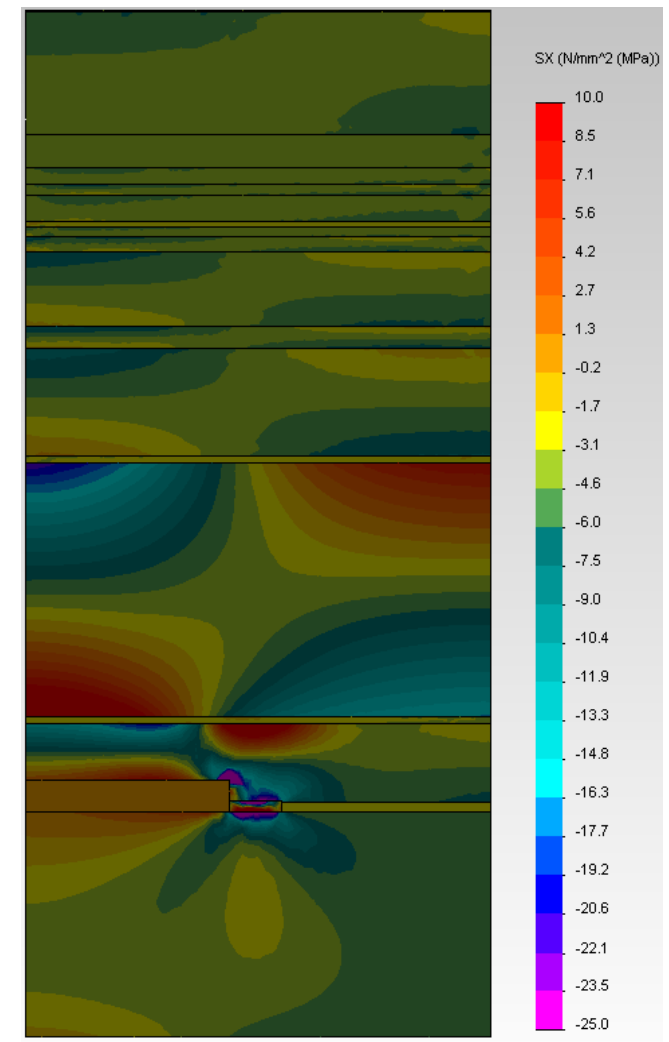

Figure 3. The curves of horizontal stresses $\sigma_{x}$ in longitudinal section YX of the extraction panels under the joint mining of seams $C_{10}{ }^{h}$ and $C_{8}^{l}$ for predominantly thin- and medium-bedded (a) and medium-and coarse-bedded (b) structure of a parting

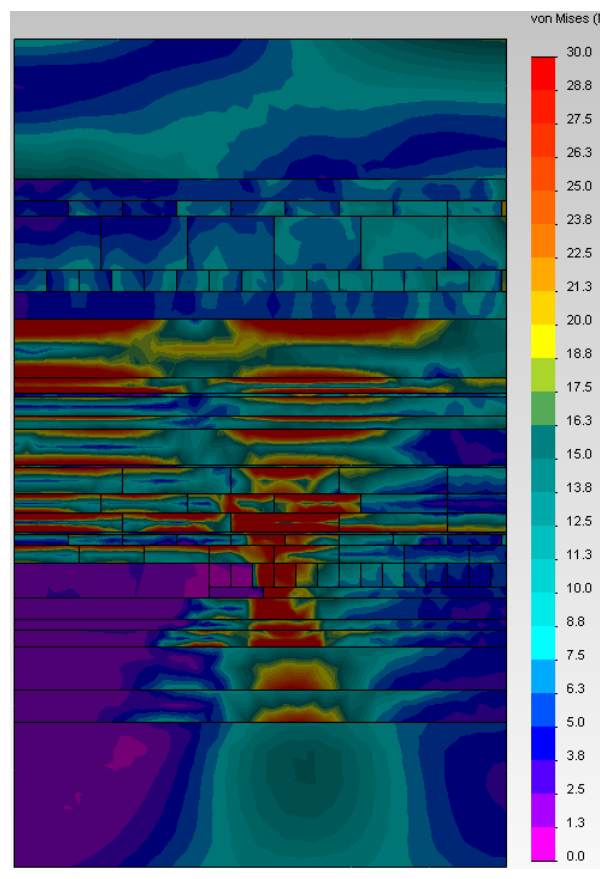

Figure 4. The distribution of stresses $\sigma$ intensity in longitudinal section of the extraction panels under the joint mining of seams $C_{10}{ }^{h}$ and $C_{9}$

Thus, even in the predominantly thin- and mediumbedded structure of a parting, with its sufficient thickness, the discontinuity along the whole thickness does not happen, but there are "focal" points of weakening in remote areas and small-scale areas of destruction in the bottom of overlying and roof of underlying seams.

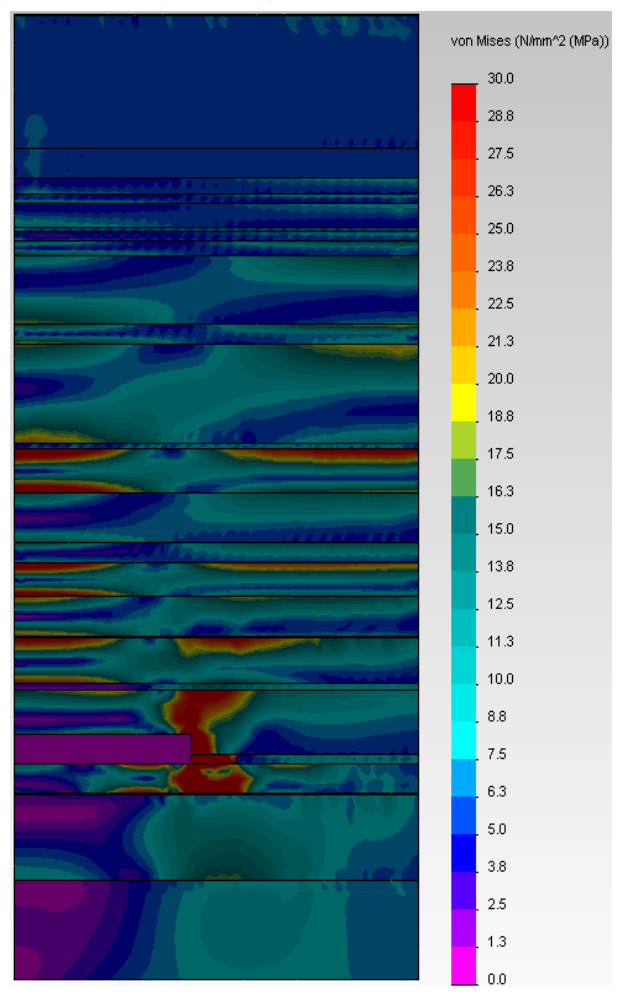

Figure 5. The distribution of stresses $\sigma$ intensity in longitudinal section of the extraction panel under the joint mining of seams $C_{10}{ }^{h}$ and $C_{8}{ }^{l}$ in the area of predominantly thin- and medium-bedded structure

In the predominantly medium- and coarse-bedded structure of a parting (Fig. 6), with its increased thick- 
ness, there is a further reduction of discontinuity areas sizes of lithotypes. Here, thanks to heavy layers depositing in the central part of a parting, it is possible to assert about its stable state and the lack of significant influence of the worked out overlying extraction panel along the seam $\mathrm{C}_{10}{ }^{h}$ on the mineable underlying extraction panel along the seam $\mathrm{C}_{8}{ }^{l}$.

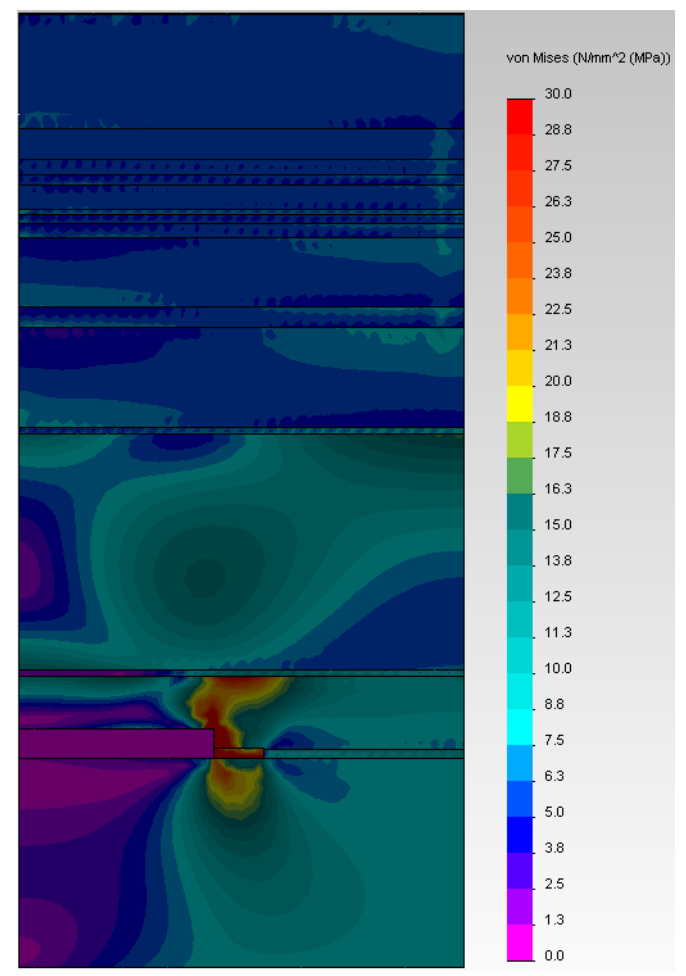

Figure 6. The distribution of stresses $\sigma$ intensity in longitudinal section of the extraction panels under the joint mining of seams $C_{10}{ }^{h}$ and $C_{8}^{l}$ in the area of predominantly medium-and coarse-bedded structure

In general, the analysis of the stresses intensity field has confirmed the previously revealed trends and specifics of mutual influence of the jointly mined seams in Western Donbas by the descending order.

\section{CONCLUSIONS}

1. The regulations have been substantiated and integrated methodology have been developed for computational experiments conducting, which allow a consistent representation of the structural transformation in parting rocks in the process of jointly mined seams by descending order. This ensures an increased rate of modeling adequacy of the geomechanical processes and obtaining of more reliable results of the SSS calculation of parting rocks.

2 . The increase in the sizes of the rock pressure manifestations area during the underlying seam excavation is significantly dependent on the thickness of a parting. Under joint mining of the seams $\mathrm{C}_{10}{ }^{h}$ and $\mathrm{C}_{8}{ }^{l}$, most manifestations do not undergo this influence, as opposed to the engineering situation of joint mining of the seams $\mathrm{C}_{10}{ }^{h}$ and $\mathrm{C}_{9}$.

3. The structure of a parting, regardless of its thickness, influences significantly on the parameters of hori- zontal stresses $\sigma_{x}$ manifestations, which may actuate the process of lithotypes components discontinuity.

4 . In the conditions of the reduced thickness of a parting (about $23-28 \mathrm{~m}$ ), by the action factor of the stresses $\sigma$ intensity field, it is highly likely to lose its stability, especially in the front and side bearing pressure zones during the mining of underlying seam. When the thickness of a parting is increased to $45-50 \mathrm{~m}$, even in the predominantly thin- and medium-bedded structure, its stability loss is not predicted at all. There only two types of disturbances arise: "focal" in the more remote areas of a parting and "continuous" but restricted in size near the mineable seams. In the predominantly medium- and coarse-bedded structure the discontinuity areas of lithotypes significantly reduce their sizes.

\section{ACKNOWLEDGEMENTS}

The authors of the article express particular gratitude to Serhii Voronin, General Director of PJSC "DTEK Pavlohradvuhillia" for the assistance in its preparation.

\section{REFERENCES}

Baysarov, L.V., Il'yashov, M.A., \& Demchenko, A.I. (2005). Geomekhanika i tekhnologiya podderzhaniya povtorno ispol'zuyemykh gornykh vyrabotok. Dnipropetrovsk: Lira LTD.

Bondarenko, V., Kovalevs'ka, I., \& Fomychov, V. (2012). Features of Carrying Out Experiment Using Finite-Element Method at Multivariate Calculation of "Mine Massif Combined Support" System. Geomechanical Processes During Underground Mining: School of Underground Mining 2012, 7-13. https://doi.org/10.1201/b13157-3

Bondarenko, V.I., Kovalevskaya, I.A., Simanovich, G.A., \& Snihur, V.G. (2014). Eksperimental'nyye issledovaniya pucheniya porod pochvy podgotovitel'nykh vyrabotok na pologikh plastakh Donbassa. Dnipropetrovsk: LizunovPres.

Bondarenko, V.I., Kovalevskaya, I.A., Simanovich, G.A., Vivcharenko, A.V., Malykhin, A.V., \& Gusev, A.S. (2014). Geomehanika nagruzheniya i raschet parametrov krepezhnoy $i$ ohrannoy sistem podgotovitelnykh vyrabotok shaht Zapadnogo Donbassa. Dnipropetrovsk: LizunovPres.

Bondarenko, V., Hardygora, M., Symanovych, H., Sotskov, V., \& Snihur, V. (2016). Numerical Methods of Geomechanics Tasks Solution During Coal Deposits' Development. Mining of Mineral Deposits, 10(3), 1-12. https://doi.org/10.15407/mining10.03.001

Chernyak, I.L. (1984). Upravleniye gornym davleniyem v podgotovitel'nykh vyrabotkakh glubokikh shakht. Moskva: Nedra.

Fadeyev, A.B. (1987). Metod konechnykh elementov $v$ geomekhanike. Moskva: Nedra.

KD 12.01.01.201-98. (1998). Raspolozheniye, okhrana i podderzhaniye gornykh vyrabotok pri otrabotke ugolnykh plastov na shakhtakh. Kiev: Ukrainskiy nauchno-issledovatel'skiy marksheyderskiy institut.

Kovalevska, I., Fomychyov, K., \& Vyvcharenko, A. (2010). Calculation Substantiation of the Yield Lock Model of the Polygonal Yieldable Support with Elongated Props by Means of Experiment. New Techniques and Technologies in Mining, 83-87. https://doi.org/10.1201/b11329-15

Kovalevs'ka, I., Vivcharenko, O., \& Snigur, V. (2013). Specifics of Percarbonic Rock Mass Displacement in Longwalls End Areas and Extraction Workings. Mining of Mineral Deposits, 29-33. https://doi.org/10.1201/b16354-7 
Simanovich, A.M., \& Srebnyy, M.A. (1976). Okhrana vyrabotok na glubokikh gorizontakh. Moskva: Nedra.

Skipochka, S.I., Mukhin, A.V., \& Chervatyuk, V.G. (2002). Geomekhanika okhrany vyyemochnykh vyrabotok shtrekov $v$ neustoychivykh porodakh. Dnepropetrovsk: Natsionalnaya gornaya akademiya Ukrainy.

Sokolov, S.A. (1997). Upravleniye sostoyaniyem massiva pri sovmestnoy otrabotke svity pologikh gazonosnykh ugol'nykh plastov. In Nedelya Gornyaka (pp. 160-162). Moskva: Moskovskiy gosudarstvennyy universitet.

SOU 10.1.001.85790.011:2007. (2007). Pidhotovchi vyrobky na polohykh plastakh. Vybir kriplennia, sposobiv i zasobiv okhorony. Donetsk: Donetskyi vuhilnyi instytut.

Usachenko, B.M. (1979). Svoystva porod i ustoychivost' gornykh vyrabotok. Kyiv: Naukova dumka.
Usachenko, B.M., Cherednichenko, V.P., \& Golovchanskiy, I.Ye. (1990). Geomekhanika okhrany vyrabotok v slabometamorfizirovannykh porodakh. Kyiv: Naukova dumka.

Zadavin, G.D. Gusel'nikov, L.V., V'yunikov, A.A., \& Litovchenko, P.I. (2009). O geomekhanicheskikh kriteriyakh vybora tekhnologicheskikh skhem pri otrabotke udaroopasnykh i podrabotannykh plastov. In Gornyy Informatsionno-Analiticheskiy Byulleten', (6), 361-368.

Zborshchik, M.P., \& Nazimko, V.V. (1986). Mekhanizm sdvizheniya porod i pereraspredeleniye napryazheniy vokrug vyrabotok, podderzhivayemykh v obrushennoy i uplotnennoy tolshche. Razrabotka Mestorozhdeniy Poleznykh Iskopayemykh, (73), 48-52.

\title{
РОЗРОБКА МЕТОДИКИ ДОСЛІДЖЕНЬ ТА АНАЛІЗ НАПРУЖЕНОГО СТАНУ МІЖПЛАСТЯ ПРИ СУМІСНОМУ І НИСХІДНОМУ ВІДПРАЦЮВАННІ ВУГІЛЬНИХ ПЛАСТІВ
}

\author{
І. Ковалевська, М. Барабаш, В. Снігур
}

Мета. Дослідження напружено-деформованого стану міжпластя при сумісному та нисхідному відпрацюванні вугільних пластів.

Методика. Дослідження виконані на основі обчислювального експерименту методом скінченних елементів, шахтних спостережень за проявами гірського тиску та їх порівняльного аналізу.

Результати. Розроблено методику дослідження стану порід міжпластя при сумісному і нисхідному відпрацюванні вугільних пластів.

Наукова новизна. Визначено закономірності зміни напружено-деформованого стану порід міжпластя у процесі спільного відпрацювання двох вугільних пластів у нисхідному порядку.

Практична значимість. Проведені дослідження дозволять підвищити стійкість виробок і забезпечити можливість їх повторного використання.

Ключові слова: вугільні пласти, сумісне відпрацювання, міжпластя, обчислювальний експеримент, стійкість

\section{РАЗРАБОТКА МЕТОДИКИ ИССЛЕДОВАНИЙ И АНАЛИЗ НАПРЯЖЕННОГО СОСТОЯНИЯ МЕЖДУПЛАСТЬЯ ПРИ СОВМЕСТНОЙ И НИСХОДЯЩЕЙ ОТРАБОТКЕ УГОЛЬНЫХ ПЛАСТОВ}

\author{
И. Ковалевская, М. Барабаш, В. Снигур
}

Цель. Исследование напряженно-деформированного состояния междупластья при совместной и нисходящей отработке угольных пластов.

Методика. Исследования выполнены на основе вычислительного эксперимента методом конечных элементов, шахтных наблюдений за проявлениями горного давления и их сравнительного анализа.

Результаты. Разработана методика исследования состояния пород междупластья при совместной и нисходящей отработке угольных пластов.

Научная новизна. Определены закономерности изменения напряженно-деформированного состояния пород междупластья в процессе совместной отработки двух угольных пластов в нисходящем порядке.

Практическая значимость. Проведенные исследования позволят повысить устойчивость выработок и обеспечить возможность их повторного использования.

Ключевые слова: угольные пласты, совместная отработка, междупластье, вычислительный эксперимент, устойчивость

\section{ARTICLE INFO}

Received: 12 October 2017

Accepted: 1 February 2018

Available online: 8 February 2018

\section{ABOUT AUTHORS}

Iryna Kovalevska, Doctor of Technical Sciences, Professor of the Underground Mining Department, National Mining University, 19 Yavornytskoho Ave., 4/57, 49005, Dnipro, Ukraine. E-mail: kovalevska i@yahoo.com

Mykhailo Barabash, Deputy Director for Production of the LLC "DTEK Energy", 57 Lva Tolstoho St, 01032, Kyiv, Ukraine. E-mail: BarabashMV@,dtek.com

Vasyl Snihur, Candidate of Technical Sciences, Director of the MM “Ternivske", PJSC "DTEK Pavlohradvuhillia", 76 Soborna Ave., 51400, Pavlohrad, Ukraine. E-mail: SnigurVG@,dtek.com 